\title{
BONYOLULT FELÜLETEK ELÕÁLLÍTÁSA ÉS MEGMUNKÁLÁSA AZ EUCLID3 CAD/CAM RENDSZERBEN
}

\author{
Gádori Attila okl. gépészmérnök
}

1. Kezdeti lehetőségek a CAD rendszerekkel

2. A számitógépes tervezés folyamata:

3. Irodalomjegyzék

\section{Kezdeti lehetőségek a CAD rendszerekkel}

A konstrukciós tervezés ma màr nagymértékben számitógépesitett. Az elsõ generációs $C A D$ rendszerek csak gépesitett rajztábla funkcióját tudták betölteni. A második generációs rendszerenel mar tapasztalhatturik intelligencia növekedést. Az egyes geometriai elcmekhez tulajdonságok is hozárendelhetök, ill. ezen alaksajátosságok egymashoz való kjapcsolatát, viszonyyát paramóteresen adhatjuk meg. A mostanában forgalmazott nagyteljesitményũ UNIX-os munkaállomásokon futó harmadik generációs CAD-CAM rendszerck a vanaciós technikát ötvözik a paraméteres szimulációvezérelt tervezéssel, és a Concurent Engineering-gel. Ahol a fökonstruktör tervein egy egész tervezócsoport dolgozhat egyszerre. E rendszerck legfóbb elônye, hogy a tervezési idô lerövidül, azaz adott idõ alatt sokkal több változatơt tudunk megvizsgálni. (Gyártási költség, méretpontosság, anyagcsökkentés, szilárdságnövelés, stb.)

Myen rondszer van a tanszéken is, nevezetesen :

\section{a Pro/Engineer és az}

Euclid 3

\section{A számitógépes gyártástervezés rendszerei:}

A gyártástervezési feladatok közül a mai CAD-CAM rondszerek az NC programozást támogatják, és nem nyujutanak segitséget a technológiai folyanat tervezéséhez. E tenületen hazai fejlesztésũ rendszereket alkalmazunk, melyek a következöek:

- Gledaft Mũveleti sorrend tervezés

- Tochnológiai változatok képzése

- Gtiprog Mủvelettervezés, forg.-i adaatok optimalizálása NC programozás

- Tauprog Müvelettervezés, forg -i adaatok optimalizálása NC programozás

- Gyártás Technológiai ciklus átfutási idejénck kiszámitása

- Laplace Gépelrendezés, anyagutak tervezése 
Az alkalmazott számítástechnikai eszközökháttér az 1. ábrán látható.

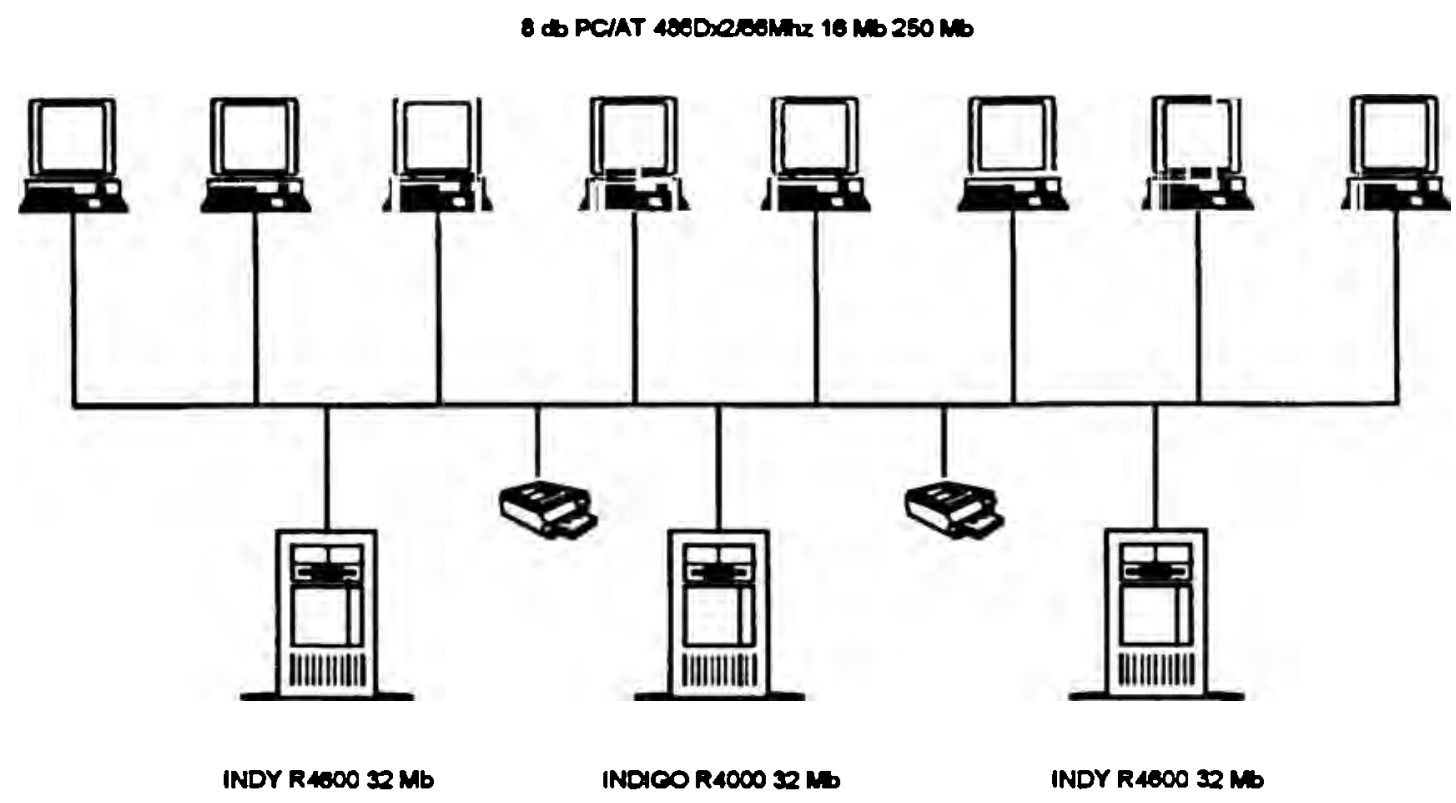

1. ábra. A gyártástervezōi CAD/CAM labor számítógépei

A rendelkezésünkre álló $\mathrm{CAD} / \mathrm{CAM}$ és gyártástervezōi rendszerek a tervezési feladatok megoldására többféle módon, számos variációban alkalmazhatóak. Egyik lehetséges változatban a tervezés menete az alábbi:

1. Az alkatrészek 3D-s modelljeinek leképzése az EUCLID3 rendszerben

2. A rajzok módosítása, esetleg az alkatrészmodell változtatása

3. A rajzdokumentációk elkészítése (mühely-, összeállítási-, robbantott rajzok)

4. GLEDAFT programmal az alkatrészek mủveleti sorrendjének az elkészítése, a technológiai változatok kidolgozása

5. TAUPROG rendszerrel az egyes mủveletek teljes megtervezése

6. EUCLID3 A megmunkálóprogram elöállítása, szimulálása, posztprocesszálása az MKC500 megmunkálóközpontra

A geometriai modellezés és megmunkálás-szimuláció eredményei képernyỗn megjeleníthetôek. Erre mutat példát a 2. ábra. 


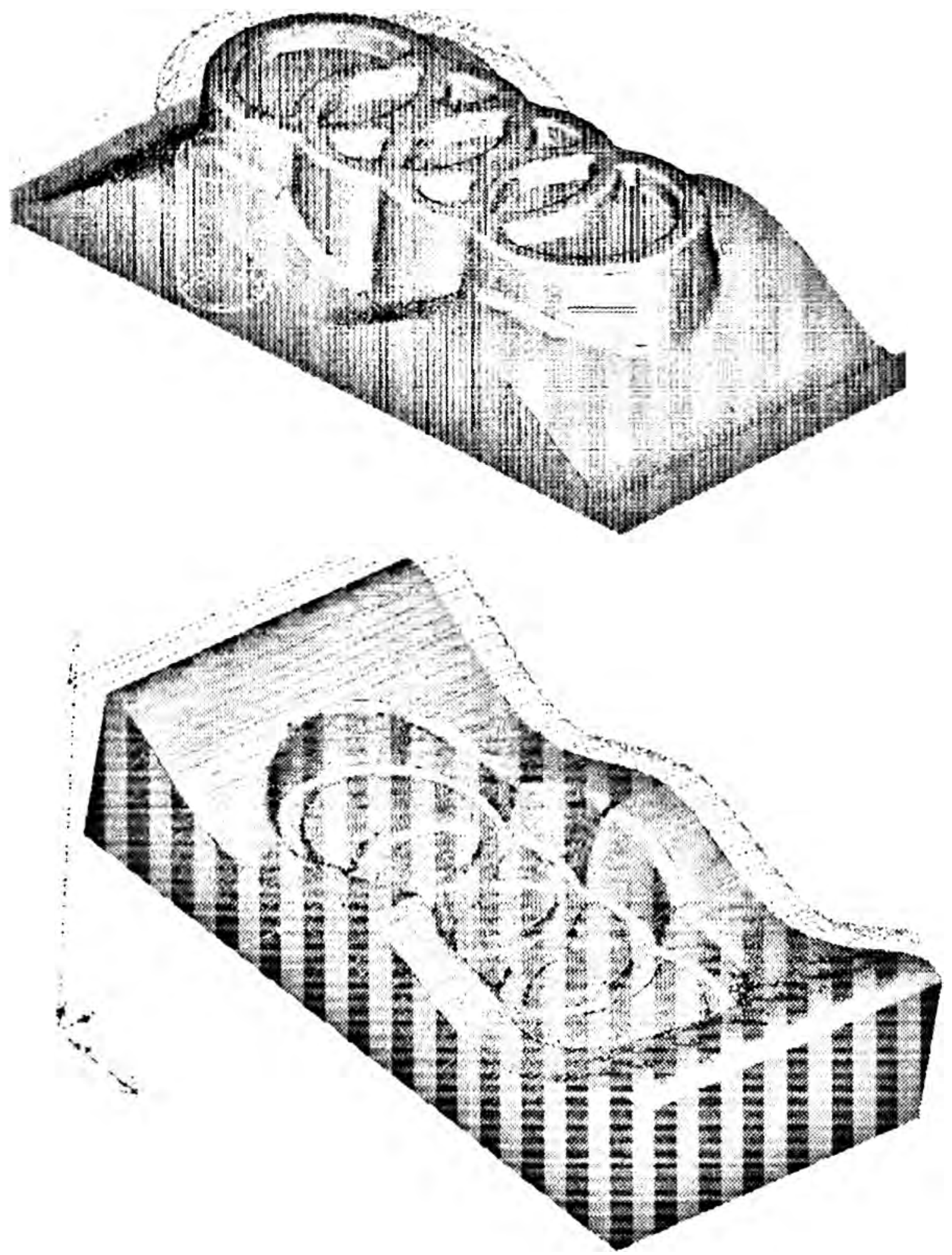

2. ábra. Az alkatrész geometriai modell és megmunkálás-szimulációs megielenitése a képernyõn. 


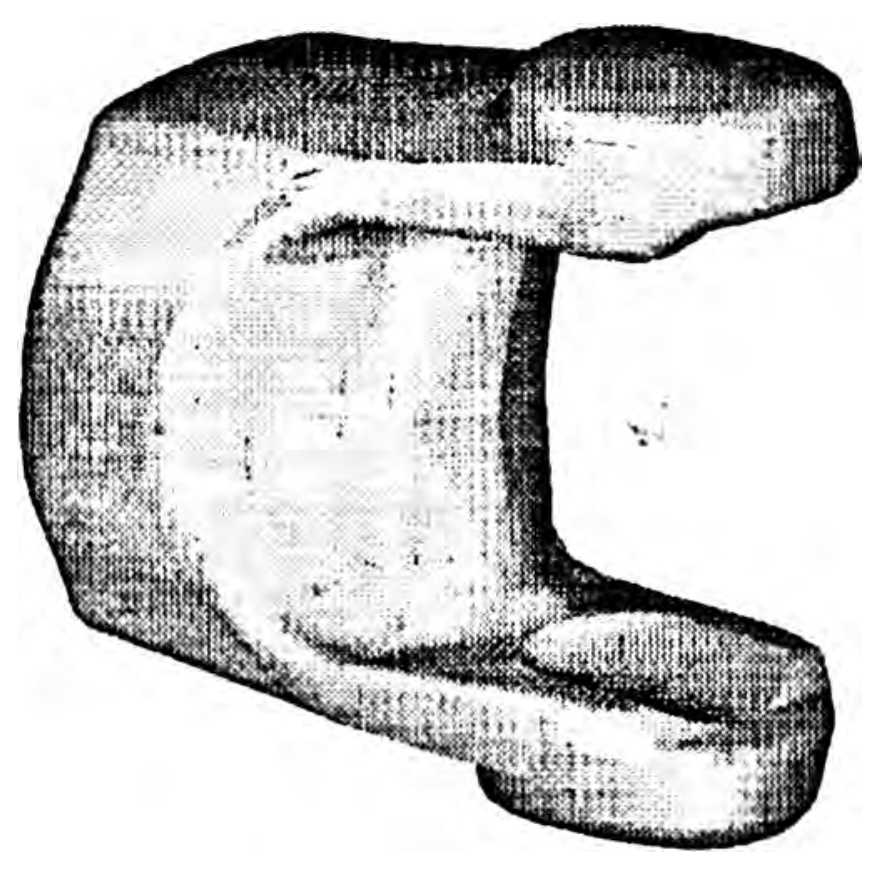

3. ábra. Szabad formájú felületekkel határolt alkatrész modellje.

A mai ipari formatervezés során a tervezők szinte teljesen elkerülik a fontos felületeken az egyenes vonalakat és sík felületeket. (PI. HI-FI torony, televizió, autó, vasaló...) Az igazi problémát az okozza, hogy a kovácsdarabok és az öntvények mind igen bonyolult felületelemekből épülnek fel. Nem lehet tökéletesen beméretezni, mindig maradnak olyan felületelemek, amelyeket a programnak magának kell besimitania a felületbe. (befoltoznia) Ehhez nagyon nagy segitséget nyújt az EUCLID, ahol a felületet határoló görbékbõl számtalan típusú felületelemet (foltot) lehet hozzáilleszteni az alkatrészhez. Ilyen bonyolult kovácsdarabot szemléltet a 3. ábra. A fentiekhez hasonló, bonyolult felületekkel határolt alkatrészek NC megmunkálásának tervezése nagyteljesitményũ $\mathrm{CAD} / \mathrm{CAM}$ rendszerek nélkül elképzelhetetlen, az NC vezérlōprogram elkészitése manuálisan rendkivül munkaigényes és hosszadalmas. Fontos tehát, hogy a jövõ mérnökei megismerjẻk a rendszerek nyújtotta lehetõségeketés felkészüljenek alkalmazásukra.

\section{Irodalomjegyzék}

[1] Matra Datavision, France, Paris, EUCLID3 Referenc Manual, 1994

[2] TAUPROG program felhasználói kézikönyv, ITC-AMT Kft, Budapest, 1988

[3] GLEDAFT program felhasználöi kézikönyv, ITC-AMT Kft, Budapest, 1988

Gádori Attila okleveles gépészmérnök 3515, Miskolc-Egyetemváros, Gépgyártástechnológiai Tanszék

Tel./Fax.: (00-36) 46 364-941 